\title{
ASSESSING THE ECONOMIC POTENTIAL OF LANDFILL MINING: REVIEW AND RECOMMENDATIONS
}

\author{
John Laurence Esguerra ${ }^{1,2, *}$, Joakim Krook ${ }^{1}$, Niclas Svensson ${ }^{1}$ and Steven Van Passel ${ }^{2}$ \\ ${ }^{1}$ Division of Environmental Technology and Management, Department of Management and Engineering, Linköping University, 58183 \\ Linköping, Sweden \\ ${ }^{2}$ Department of Engineering Management, Faculty of Business and Economics, University of Antwerp, Prinstraat 13, 2000 Antwerp, \\ Belgium
}

Article Info:

Received:

5 July 2019

Revised:

29 October 2019

Accepted:

31 October 2019

Available online:

23 December 2019

Keywords:

Economic assessment

Life cycle costing

Landfill mining

Landfill management

\begin{abstract}
As landfill mining (LFM) gains public attention, systematic assessment of its economic potential is deemed necessary. The aim of this review is to critically analyze the usefulness and validity of previous economic assessments of LFM. Following the life cycle costing (LCC) framework, (i) the employed methods based on goal and scope, technical parameters and data inventory, and modelling choices were contrasted with respect to (ii) the synthesized main findings based on net profitability and economic performance drivers. Results showed that the selected studies $(n=15)$ are mostly case study-specific and concluded that LFM has a weak economic potential, hinting at the importance of favorable market and regulation settings. However, several method issues are apparent as costs and revenues are accounted at different levels of aggregation, scope and scale-from process to sub-process level, from private to societal economics, and from laboratory to pilot-scale, respectively. Moreover, despite the inherent large uncertainties, more than half of the studies did not perform any uncertainty or sensitivity analyses posing validity issues. Consequently, this also limits the usefulness of results as individual case studies and as a collective, towards a generic understanding of LFM economics. Irrespective of case study-specific or generic aims, this review recommends that future assessments should be learning-oriented. That is, uncovering granular information about what builds up the net profitability of LFM, to be able to systematically determine promising paths for the development of cost-efficient projects.
\end{abstract}

\section{INTRODUCTION}

The shift from a linear to a circular economy has influenced the perception of landfills as final waste deposits. Apart from minimizing waste flows through circular design, production, and use (Ellen MacArthur Foundation, 2013), keeping resources in the loop also extends through considering landfills as anthropogenic stocks (Cossu and Williams, 2015; Johansson et al., 2012; Jones et al., 2013; Krook and Baas, 2013). The potential of extracting these previously deposited resources is increasingly gaining public attention (Financial Times, 2018; World Economic Forum, 2017) and is commonly referred to as landfill mining (LFM).

Although LFM has been in practice for nearly 70 years, the motivation for performing it has changed over time ( $\mathrm{Ho}$ gland et al., 2010). As a concept, it has gradually progressed from an initial focus on local landfill management issues and pollution risks, to an increasing emphasis also on the recovery of deposited materials and energy resources
(Krook et al., 2012). The most recent concept of LFM even targets a zero-waste approach by including innovative resource recovery technologies, as well as extending the typical process chain (i.e. excavation, separation, and thermal treatment) with more downstream residue valorization processes (Danthurebandara et al., 2015a; Hernández Parrodi et al., 2018; Jones et al., 2013). Furthermore, the motivation for such projects has been suggested to go beyond traditional economic and environmental impacts by also considering revitalization of ecosystem services (e.g. landuse services) and broader sustainability perspectives (Burlakovs et al., 2017). Although these changes in the LFM concept try to capture a wider societal potential, there is also an inevitable increase in complexity when it comes to both its realization and sustainability consequences.

At present, however, the recovery of materials and energy resources from landfills remains at the niche level or at a laboratory to pilot scale level (Johansson et al., 2012). This gives a hint on the compelling challenges for realizing 
such projects. Beyond the technological challenges, the implementation of LFM is also subject to the complex web of political, organizational, environmental, and economic considerations (Hermann et al., 2016; Johansson et al., 2017; Krook et al., 2015; Van Der Zee et al., 2004), which is common to emerging concepts (Hekkert et al., 2007). In Europe, although LFM failed to be integrated into the recent amendment of the EU Landfill Directive (1999/31/EC), its implementation is neither prohibited (European Parliament, 2018). In fact, several LFM research projects are being funded (European ELFM Consortium, 2019), especially in the view of landfills as secondary sources for critical metals (Løvik et al., 2018). Moreover, going beyond research and envisioning a full-scale and widespread LFM implementation, development of sustainable projects should be assured to attract the support of various stakeholders (Hermann et al., 2014; Krook et al., 2018a; Van Der Zee et al., 2004).

To enable structured assessments of various systems (e.g. products, services, projects and policies), different systems analysis tools (Ahlroth et al., 2011; Finnveden and Moberg, 2005) have been widely used addressing separated or integrated sustainability aspects (Guinée, 2016; Heijungs et al., 2013). These assessments can serve multiple purposes (Finnveden and Moberg, 2005; ISO, 2006a; Swarr et al., 2011). A common objective of such studies is to obtain an accurate result on the net performance of certain systems to support decisions on capital investments or for marketing reasons. In contrast to such decision-oriented purposes, systems analysis tools can also be used to obtain a more in-depth understanding of what builds up the net performance of the system in question. Such learningoriented purposes are often used to identify strategies and measures to further improve the performance of various systems through optimization and design development. These are particularly useful in guiding the development of emerging concepts through early assessments, or so-called ex-ante assessments (Cucurachi et al., 2018; Fleischer et al., 2005; Wender et al., 2014).

Although most decisions related to real-life projects rely on the economic potential (Martinez-Sanchez et al., 2015), studies accounting for environmental impacts are more common within the field of waste management (Laurent et al., 2014a, 2014b). When it comes to LFM, however, several economic assessments were done in recent years (Krook et al., 2018b). However, there is not yet any systematic synthesis of their main findings regarding the feasibility and challenges for the implementation of such projects. In addition, acknowledging that LFM is still an emerging concept with large practical knowledge deficits (e.g. lack of actual data, setting of best estimates, and upscaling), inherent large assessment uncertainties are expected and have to be properly addressed as pointed out in ex-ante assessments (Clavreul et al., 2012; Hellweg and Milà i Canals, 2014; Martinez-Sanchez et al., 2015). Thus, a methodological review of what uncertainties were accounted for and how they were subsequently handled is deemed necessary to reveal the quality of the main findings.

This review aims to critically analyze previous economic assessments of LFM in terms of the usefulness and validity of their provided results. In doing so, individual objecti- ves and employed methods are considered as well as their collective contribution towards a generic understanding of the economic potential of LFM. Here, usefulness therefore both corresponds to the fulfilment of the intended objective of the assessment and the type of knowledge of relevance for LFM implementation that is addressed. The validity refers to whether the expected methodological rigor was followed according to certain standards (Swarr et al., 2011). Apart from that, different objectives of economic assessments require different methodological approaches, assuring validity also qualifies the real usefulness of provided results. That is, the results may have perceived usefulness as presented in the studies, but the corresponding validity may indicate otherwise, revealing their real usefulness. The specific research aims are (i) to review the methods in terms of goal and scope definition, key technical parameters and data inventory, and key modelling choices, and (ii) to synthesize main findings in terms of net performance and economic performance drivers. In the end, this review reflects on the key methodological shortcomings and provides a recommendation to improve the usefulness and validity of future economic assessments to support further LFM development and implementation.

\section{METHODOLOGY}

\subsection{Search and selection of studies}

The identification of studies dealing with the economic assessment of LFM was performed through a literature search using multidisciplinary science databases such as Scopus (1960-present) and Web of Science (1975-present) with restriction in publication date until 2017 . To be able to account for all possible synonymous terms, the following search strings were used (i) for economic assessment: (economic* OR financial OR cost* OR benefit* OR expense $^{\star}$ ) AND (assessment OR analysis OR feasibility OR evaluation OR impact*); and (ii) for LFM: "landfill mining". It should be noted that this search may not be exhaustive of all LFM studies as there is also proprietary grey literature by private companies and consultancy firms. In addition, it was assumed that possible search terms such as landfill reclamation and landfill rehabilitation meant LFM without special emphasis on resource recovery, which was beyond the scope of this review.

The selection procedure had a particular focus on studies available as full papers (e.g. journal articles, conference proceedings, technical reports) with quantitative economic assessments covering the entire LFM process chain. It was done to acknowledge that LFM is composed of an array of processes and technologies and to allow for a balanced evaluation of the main findings and employed methods among the studies. In summary, a two-step studies search and selection procedure (Pinior et al., 2017) was used as illustrated in Figure 1.

The first step involved the search for studies in the databases (primary search) while the second step retrieved studies from the reference lists of the previously selected studies (secondary search). Duplicate studies from the two databases were excluded. To narrow down the identified studies from databases and reference lists, preliminary 


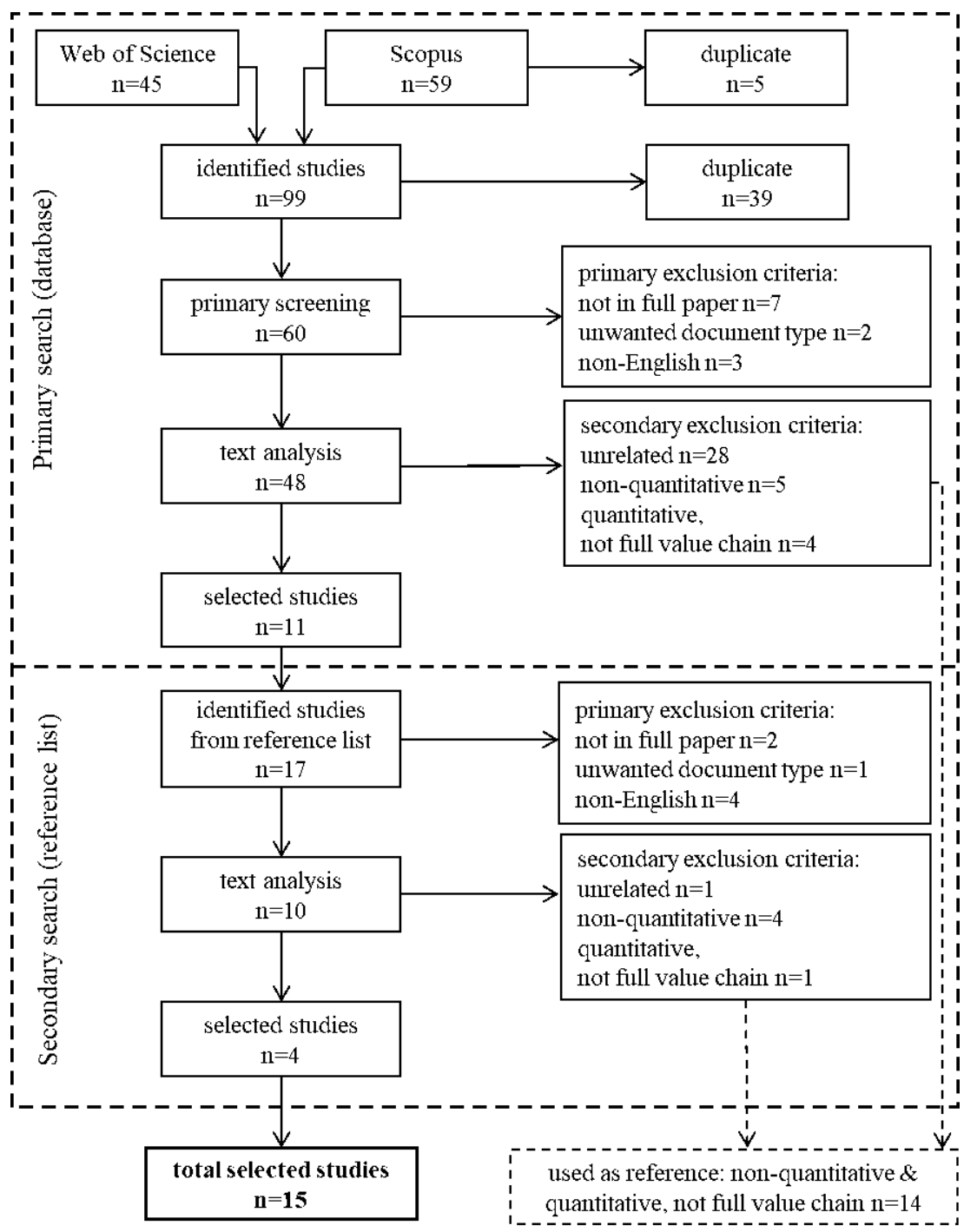

FIGURE 1: Flow diagram describing the literature search and selection procedure and the corresponding number of studies ( $n$ ) for the review of economic assessment of landfill mining.

exclusion was done based on the content of title and abstract with the following criteria: (i) unavailability in full paper such as conference abstracts, (ii) unwanted document type such as science magazines and conference reviews, and (iii) written in non-English language. Subsequently, secondary exclusion was done based on the content of the full paper with the following criteria: (iv) being unrelated, the paper was not about LFM or did not include any economic assessment at all; (v) being non-quantitative, these papers were typically about economic frameworks suggesting cost and benefit items; and (vi) being quantitative, the paper did not consider the entire LFM process chain. The studies in the latter two exclusion criteria (v-vi) were not completely excluded but were instead used for further exemplification and elaboration in the discussion part.

\subsection{Analytical review approach}

The overall analytical review method was divided into three main parts (Figure 2). The first two parts focused on the critical review of (i) methods and (ii) main findings. The- se parts aided to contextualize the provided results, thereby offering a better understanding of the study objectives and limitations prior to the subsequent (iii) assessment of usefulness and validity of their provided results. Categories for usefulness were introduced here in terms of the four types of questions that the studies can address. These questions were based on two dimensions, that is the type of analysis (case study-specific or generic) and the type of application (decision-oriented or learning-oriented) that the studies intend to fulfill. In the end, these categories were also used to discuss what type of usefulness is common in the selected studies, as well as what type is relevant to support further LFM development and implementation.

\subsubsection{Methods review}

The methods review was based on several analytical criteria (Table 1) to determine the specific goals and corresponding methodological rigor of the studies. These criteria were selected and modified based on the main steps of the code of practice in life cycle costing (LCC by Swarr et 


\begin{tabular}{l}
\begin{tabular}{l}
\multicolumn{1}{|c|}{ Methods review } \\
$\begin{array}{l}\text { Goal and scope definition } \\
\text { Technical parameters and data inventory } \\
\text { Modelling choices }\end{array}$
\end{tabular} \\
\begin{tabular}{|l} 
Assessment of usefulness and validity \\
Net profitability \\
Main cost and revenue items
\end{tabular} \\
$\begin{array}{l}\text { What type of questions regarding the economics of LFM can the different } \\
\text { studies address and for which specific stakeholder? } \\
\text { Are the provided results trustworthy? }\end{array}$ \\
\hline
\end{tabular}

FIGURE 2: The overall analytical review approach.

al., 2011) and related reviews on systems analysis of waste management systems (Astrup et al., 2015; Laurent et al., 2014a, 2014b; Martinez-Sanchez et al., 2015). The main steps are goal and scope definition, technical parameters and data inventory, and modelling choices. By going through these main steps, the inherent uncertainties in assessing the economic performance of LFM were highlighted.

Goal and scope definition were analyzed to determine the type of analysis (case study-specific or generic) and the type of application (decision-oriented or learning-oriented) that the individual studies intended to fulfill, which corresponds to the perceived usefulness. The type of application refers to whether the main objective of the study was to obtain accurate results on the economic feasibility of LFM (decision-oriented) or if the emphasis was rather on assessing what factors build up such performance (learning-oriented), while the type of analysis instead refers to the explored settings for LFM and thus which scenarios were assessed in the studies. According to Laner et al. (2016), LFM could be realized in a wide range of different settings, and these variations can be classified at different levels such as site level (e.g. waste composition, landfill size, etc.), project level (e.g. technological and organizational set-up for separation, thermal treatment, and/or further residue valorization), and system level (e.g. surrounding policy and market conditions). Here, these different levels were used to categorize which scenario variations have been explored in the economic assessments of LFM, both for case specific and more generic studies. For a more comprehensive description of the assessed LFM scenarios, the corresponding geographical, technological and temporal scopes were also classified as well as the applied economic perspective (i.e. conventional LCC, environmental LCC and social LCC according to Swarr et al., 2011).

To investigate the technical specificity and corresponding data quality, descriptions of employed technical parameters and data inventories were analyzed for each LFM value chain process (i.e. separation, thermal treatment, and residue management), also including landfill settings and waste composition. The respective data sources were noted in terms of whether the studies used primary data, secondary data, mixed primary and secondary data, or were not specified at all. Specific modelling choices were analyzed in terms of the considered reference scenario (incumbent landfill management alternative instead of LFM), externalities (environmental and social), marketability and market prices of recovered resources, and economic indicator (direct or discounted cash flow analysis). In addition, the handling of uncertainties was also enumerated in terms of the type of employed uncertainty and sensitivity analyses. Parametric uncertainty analysis accounts for the uncertainties of input parameters (range of values instead of an absolute value per parameter), which gives additional information on the confidence level of the provided results. Sensitivity analysis, on the other hand, accounts for the robustness of results when input parameters are changed either one at a time as in local sensitivity analysis, or simultaneously as in global sensitivity analysis (Saltelli et al., 2008).

\subsubsection{Synthesis of main findings}

The main findings were assessed in terms of the reported net performance and main economic drivers. For net performance, apart from being net profitable or not, potentially profitable cases were noted if at least one of the considered scenarios generated a positive economic result. Main economic drivers referred to the cost and revenue items with the highest values. Cost items were noted as expenditures at each LFM process (i.e. excavation, separation, thermal treatment, transportation, and residue disposal), while revenue items were categorized into direct revenues from process outputs (e.g. material sales, energy sales and value of reclaimed land or landfill void space) and indirect revenues caused by avoided aftercare costs or governmental support (e.g. tax breaks or other policy instruments internalizing environmental externalities). Moreover, the criticalities related to the synthesis of main findings and the corresponding interpretation of subsequent results were also highlighted.

\subsubsection{Assessment of usefulness and validity}

From the goal and scope definition, the perceived usefulness of the reviewed studies was categorized based on the type of analysis (case study-specific or generic) and the type of application (decision-oriented or learning-oriented). Here, these two dimensions were taken further and used as an analytical framework for assessing both the usefulness and validity of the synthesized main findings. Usefulness was described through enumerating the type of questions the studies could answer, while validity was described through the specific methodological rigor focusing on the extent of scenario development and employed uncertainty 
TABLE 1: Analysis criteria addressed in this review. The classification under each analysis criterion is listed and described (in italics) when deemed necessary. "Mixed" refers to either comparison or combination of preceding stated classification.

\begin{tabular}{|c|c|}
\hline Analysis Criteria & Classification \\
\hline \multicolumn{2}{|l|}{ Goal \& scope definition } \\
\hline Type of application & Decision-oriented, learning-oriented \\
\hline Type of analysis & $\begin{array}{l}\text { Case study-specific: single-subject assessment (case study only), comparative assessment (case study + } \\
\text { scenarios of varying conditions at project and/or system level) } \\
\text { Generic: (case study + scenarios of varying conditions at site, project and system levels) }\end{array}$ \\
\hline Geographical scope & Continent, country, region, multiple sites, single site \\
\hline Technological scope & $\begin{array}{l}\text { Separation: conventional, advanced, mixed (depending on the number of secondary materials recovered) } \\
\text { Thermal treatment: incineration, plasma gasification, mixed, internal/external } \\
\text { Residue management: re-landfill (internal/external), metal recovery, construction aggregates } \\
\text { Reference scenario, avoided costs if LFM is not performed: do nothing, aftercare, aftercare with energy } \\
\text { recovery }\end{array}$ \\
\hline Temporal scope & Project duration corresponds to total process capacity $(\mathrm{Mg} / \mathrm{yr})$ \\
\hline Economic perspective & $\begin{array}{l}\text { Conventional LCC (C-LCC) purely financial, environmental LCC (E-LCC) accounts environmental costs/sav- } \\
\text { ings, social LCC (S-LCC) accounts broader societal costs/benefits }\end{array}$ \\
\hline \multicolumn{2}{|l|}{ Technical parameters and data inventory } \\
\hline Landfill settings and waste composition & $\begin{array}{l}\text { Type: municipal solid waste (MSW), industrial waste (IW), mix MSW-IW, mixed } \\
\text { Size: Small ( }<1 \mathrm{Mt}) \text {, medium }(1 \mathrm{to}<10 \mathrm{Mt}) \text {, large }(>10 \mathrm{Mt}) \\
\text { Composition: Material fraction, material fraction + chemical composition, not specified } \\
\text { Data source: primary, secondary, mixed }\end{array}$ \\
\hline Separation & $\begin{array}{l}\text { Separation efficiency } \\
\text { Data source: primary, secondary, mixed }\end{array}$ \\
\hline Thermal treatment & $\begin{array}{l}\text { Energy efficiency } \\
\text { Data source: primary, secondary, mixed }\end{array}$ \\
\hline Residue management & $\begin{array}{l}\text { Amount of secondary waste/intermediary materials produced } \\
\text { Data source: primary, secondary, mixed }\end{array}$ \\
\hline \multicolumn{2}{|l|}{ Modelling choices } \\
\hline Reference scenario & Length of reference scenario implementation \\
\hline Externalities & Valuation of cost/benefit items for E-LCC and S-LCC \\
\hline Marketability and market prices & $\begin{array}{l}\text { Materials (ferrous metals, nonferrous metals, construction aggregates, RDF, valorized residues, etc.), } \\
\text { energy (electricity, heat), land, landfill void space }\end{array}$ \\
\hline Economic indicator & $\begin{array}{l}\text { Direct cash flow, discounted cash flow (accounts time-value of money i.e. lower value for future revenues } \\
\text { and avoided costs) }\end{array}$ \\
\hline Uncertainty \& sensitivity analysis & Parametric uncertainty analysis, local sensitivity analysis, global sensitivity analysis, mixed, none \\
\hline
\end{tabular}

and sensitivity analyses, apart from other possible general issues such as transparency in data inventories and modelling choices. This was done acknowledging the emerging character of LFM with inherent large uncertainties that must be handled.

Categories A (What is the economic outcome of a specific LFM project?) and B (How could the economic performance of a specific LFM project be improved?) cover a specific case in the perspective of landfill owner and/ or project manager. While Categories $C$ (What is the economic potential of large-scale implementation of LFM in a region?) and D (How could profitable LFM projects be developed through selection of sites, project set-ups, and policy and market conditions?) are much broader that cover wider regional scope and in the perspective of several stakeholders such as LFM contractors, investors, policymakers, and/or researchers. Methodologically, it follows that the scenario development for both Categories $A$ and $B$ are limited to variation at the project level (e.g. technological and organizational set-up for separation, thermal treatment, and/or further residue valorization). While for both Categories $C$ and $D$, they also consider variation at the site level (e.g. waste composition, landfill size, etc.) and system level (e.g. surrounding policy and market conditions). Regarding the employed sensitivity analysis, local sensitivity analysis is proven to be inefficient in revealing the underlying interactions among the parameters, unlike the global sensitivity analysis (Ferretti et al., 2016; Saltelli and Annoni, 2010) that is particularly relevant for the learning-oriented type of application. Hence, local sensitivity analysis is at least expected for Categories A and C as they only intend to know the net performance, while global sensitivity analysis is expected for Categories B and D ("How" questions) as they are after the principles of performance. Lastly, to handle the inherent parametric uncertainties, parametric uncertainty analysis is expected for all Categories to properly account for the variation of data values and the extent of their effect to the spread of the study results.

This analytical framework helped in revealing the difference between the perceived usefulness (categorization of studies based on the stated aim) and the real usefulness with the corresponding validity of the provided results (assessment of methodological rigor based on the stated aim). For instance, issues on validity due to unsatisfactory methodological rigor directly led to problematic real usefulness. Proceeding discussion focused on the applications 
and limitations of the selected studies under each Category, and the corresponding recommendations for improvement in terms of economic assessment features and how it can methodologically be performed. Furthermore, synthesis discussion on how economic assessments can be used to facilitate the development of cost-efficient LFM projects and to guide future research prioritization for the LFM area as a whole were underscored.

\section{RESULTS AND DISCUSSION}

\subsection{Goal and scope definition}

In total, this review includes 15 studies (see Appendix A). Most of them involve specific LFM case studies with a decision-oriented type of economic analysis. The key objective of these studies is thus to assess the net performance of a specific LFM project, often by accounting for a limited number of scenario alternatives. Several studies $(n=6)$, however, only assess the economic outcome of a single scenario for realizing a specific LFM project. The extent of assessed LFM processes and explored scenario alternatives in all of the reviewed studies are shown in $\mathrm{Fi}$ gure 3 .

At the site level, variation in waste composition is seldom accounted for $(n=1)$ in the explored scenarios, since most of the studies address a specific landfill. Different waste compositions are considered, such as municipal solid waste (MSW, $n=6)$, industrial waste (IW, $n=3$ ) and mixed MSW and IW (MSW-IW, $n=5)$. For the same reason, variation in system-level conditions $(n=3)$ is also seldom investigated. The explored system-level variation is limited to inclusion/exclusion of re-landfilling tax, availability/unavailability of the market for recovered materials, and varying the required length of time of the reference scenario. The reference scenario is classified at both site and system level variation together with land resources. The former depends on both the regulatory requirements as well as the type of landfill waste composition (do nothing $n=1$, aftercare $n=6$, aftercare with energy recovery $n=3$ ), while the latter depends on both market conditions and the location of the landfill site (land recovery $n=5$, landfill void space recovery $n=4$, mixed $n=4)$. Not all of the studies accounted for these two aspects, hence underestimating the economic performance of LFM by missing possible revenue items.

Variation at the project level is commonly investigated $(n=8)$, and is done in different ways in individual studies. For the separation process, investigated technologies include a conventional separation process $(n=5)$ that recovers metals and construction aggregates, or an advanced separation process $(n=7)$ that additionally recovers combustibles (including refused derived fuel or RDF) and glass. A comparison between these separation technologies is also performed in the rest of the studies $(n=3)$. For the thermal treatment process, investigated technologies include incineration $(n=3)$, gasification $(n=3)$, or the comparison between the two. Apart from these variations in technological set-up, variation in organizational set-up $(n=3)$ is also investigated, which means the thermal treatment process is considered either internal or external to the LFM project. Similarly, variation in organizational set-up $(n=5)$ is investi- gated for the disposal of separation residue, while the rest have individually considered either internal $(n=6)$ or external $(n=4)$ disposal. For thermal treatment residue, apart from the disposal in hazardous landfill $(n=3)$, further valorization such as metal recovery from incineration bottom ash $(n=1)$ and construction aggregates $(n=2)$ from plasma gasification slag is also considered. It is notable that fewer studies investigated more downstream processes starting from thermal treatment, which is reflective of the emerging character of LFM.

Variation in scope is also observed geographically, technologically, and temporally. Regarding the geographical scope, a single landfill site $(n=9)$ is typically considered, while some also covered a wider scope in terms of national $(n=3)$ such as Scotland, Sweden, and Greece; regional $(n=2)$ such as Flanders in Belgium and Styria in Austria; and also continental $(n=1)$ such as entire Europe. It is notable that most of the selected studies come from Europe $(n=12)$, and only a few come from Asia $(n=2)$ and North America $(n=1)$. The countries where these case studies are located are categorized as nations with high-income economies (World Bank, 2016), with more stringent standards expected for landfill management. This situates LFM to having a promising business case due to a favorable market (i.e. higher material prices) and aftercare obligations (i.e. higher avoided costs). Regarding the temporal scope, most studies considered the specific LFM project duration. As different case studies are considered, project duration depends on landfill settings, processing capacity, and length of landfill aftercare. Regarding the economic perspective, most of the studies were assessed based on conventional LCC $(n=8)$, while the rest were based on environmental LCC $(n=5)$ including green energy certificates and carbon emission trading, and social LCC $(\mathrm{n}=2)$ including health risk reduction and employment. This highlights that most of the studies were intended for LFM practitioners with a private economic view. Although a broader sustainability consideration has been suggested, this also implies additional complexity in terms of the valuation of external cost and revenue items (Burlakovs et al., 2017).

\subsection{Key technical parameters and data inventory}

\subsubsection{Landfill settings and waste composition}

In terms of landfill settings, studies consider varying landfill sizes, including small $(<1 \mathrm{Mt}, \mathrm{n}=6)$, medium $(1-10$ $\mathrm{Mt}, \mathrm{n}=5)$ and large (>10Mt, $\mathrm{n}=4)$ sites. The case studies are typically described in terms of the mass of landfill waste and seldom in terms of more specific information such as area, depth, and density. Without such information, the effect of excavation and internal transport logistics to the economic performance of LFM may be overlooked (Hogland et al., 2018; Hölzle, 2019). In terms of waste composition, it is typically presented by material fractions (e.g. metals, paper, wood, aggregates, etc.) and seldom by chemical composition. Consequently, it is difficult to qualify the material outputs as to whether they satisfy standard material quality requirements for the proceeding processes, may it be thermal treatment, material sales or even disposal. 


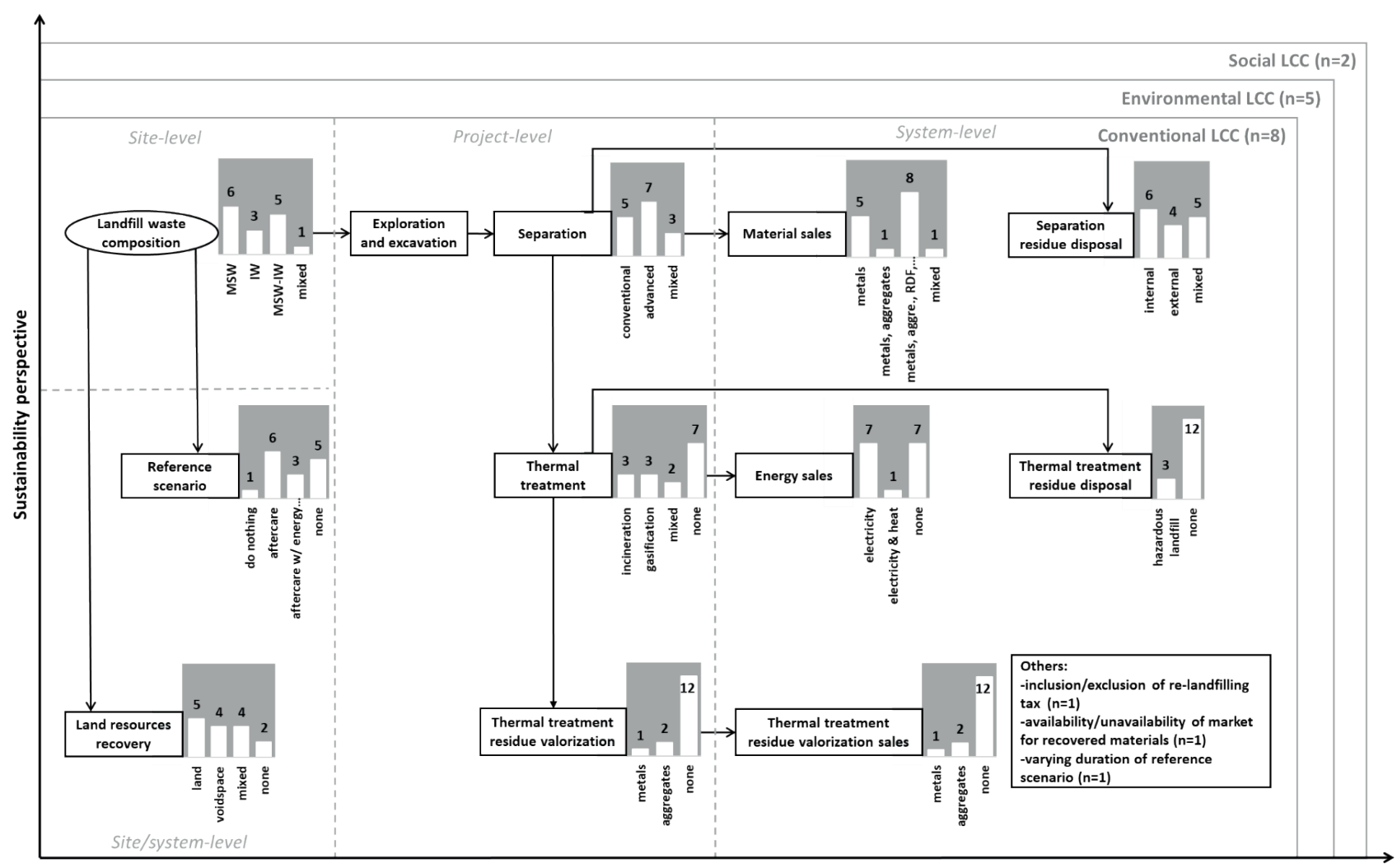

Complexity of assessment

FIGURE 3: LFM processes included in the selected studies $(n=15)$, with their respective variations categorized at different levels such as site, project and system (in dashed lines). The complexity of economic assessment is expected with the extended technological scope and broader sustainability perspective. "Mixed" refers to either comparison or combination of preceding stated classifications, while "none" refers to studies which excluded, or implicitly included, such processes.

Regarding data sources, most of the studies use primary sources $(n=9)$, and the rest use secondary $(n=4)$ and mixed sources $(n=2)$. Only a few of the primary sources are based on full-scale excavation $(n=2)$, and the rest $(n=7)$ are based on logbooks, preliminary sampling campaigns, and pilot-scale excavation. The apparent use of primary sources corresponds to case-specific studies, while the use of secondary and mixed sources corresponds to either hypothetical case studies or studies with a wider geographical scope. The average of waste compositions from different landfills is used to represent continental (Van Vossen and Prent, 2011), national (Ford et al., 2013; Frändegård et al., 2015), and regional levels (Damigos et al., 2016; Danthurebandara et al., 2015b; Van Passel et al., 2013). Clearly, there is a large uncertainty to be accounted for, both within and among reported waste compositions (Hernandez Parrodi et al., 2018; Hogland et al., 2018; Hölzle, 2019).

\subsubsection{Separation}

Specifics of the separation process are typically presented through process flow diagrams. However, the corresponding separation efficiencies and the underlying machine specifics are seldom stated. Separation efficiencies are from $40 \%$ to $100 \%$ of the total waste composition, with most studies adopting the higher end. In addition, most of the primary sources are based on laboratory-scale separation. For hypothetical cases, secondary sources are often not closely related to the studied case but rather are obtained from industry estimates for fresh MSW processing. Similarly, secondary costs data are directly adopted from different geographical and temporal contexts. To assure representativeness to the case study of interest, these data have to be harmonized. Temporal cost harmonization can be done through a financial approach to remove the effect of inflation using indicators such as a gross domestic product deflator and consumer price index, while geographical cost harmonization can be achieved through purchasing power parity (World Bank, 2014).

\subsubsection{Thermal treatment}

Irrespective of the type of thermal treatment technology, energy efficiencies are reported from $25 \%$ to $30 \%$, accounting for optimum performance. For this process, the considered RDF quality requirement in terms of input heating value is from 16 to $20 \mathrm{MJ} / \mathrm{kg}$, which corresponds to high-quality input materials (Bosmans et al., 2013). Both of these specifics, however, are often based on secondary sources, either from existing pilot plants for plasma gasification or large-scale plants for incineration. Such plants use other process input materials such as fresh municipal solid waste that is not representative of landfill waste. For the secondary cost data, as previously stated, temporal and geographical cost harmonization is not performed. 


\subsubsection{Residue management}

The amount of residue from the separation process is not clearly stated, despite the fact that about $40 \%$ to $80 \%$ of the total excavated waste ends up as residues (Hernandez Parrodi et al., 2018). A similar issue on material flow transparency is observed for the valorization of residue from thermal treatment. Specifically, separation efficiency and market quality requirements are seldom mentioned for the metal recovery and construction aggregates production from incineration and plasma gasification processes, respectively. In addition, information about the hazardous waste fraction is seldom noted that could significantly affect the total re-landfilling costs. Hazardous waste is significantly more expensive (100 to 200 Euro/ton) than its nonhazardous counterpart (3-100 Euro/ton) (Confederation of European Waste-to-Energy Plants, 2017).

\subsection{Key modelling choices}

\subsubsection{Reference scenario}

For the potential avoided costs, a reference scenario is stated acknowledging that there is an incumbent landfill management alternative instead of LFM. However, a significant number of studies $(n=5)$ do not mention any reference scenario. However, for the ones that are mentioned, specific technical requirements and costs of aftercare vary widely depending on national or regional regulatory requirements. For example, landfill cover is commonly required but not in the Netherlands (Van Vossen and Prent, 2011) and Denmark (Rosendal, 2015), or none is required at all (do nothing) as in Sri Lanka (Danthurebandara et al., 2015b). Moreover, the model for leachate production and landfill gas emission is seldom specified, which directly affects the amount of emissions and consequent treatment costs. Also, the length of the aftercare period varies from 25 to 100 years, with 30 years as the most commonly used. This uncertainty is primarily due to the vague description in Article 12d of the EU Landfill Directive (1999/31/EC), which states that aftercare duration halts when "the competent authorities consider the landfill likely to cause a hazard to the environment".

\subsubsection{Externalities}

Some studies $(n=5)$ internalize environmental benefits, which are limited to avoided climate impact in terms of carbon dioxide equivalent $\left(\mathrm{CO}_{2}\right.$ eq.). Different databases are used to quantify process-related environmental emissions (subsequently converted to $\mathrm{CO}_{2}$ eq.), such as Bilan Carbone $^{\mathrm{TM}}$ (Association Bilan Carbone, 2007), PROBAS (German Federal Environmental Agency, 2013), and Ecolnvent v2.2 (Ecoinvent, 2010). According to the ILCD Handbook (European Commission-Joint Research Center, 2010), the selection of database must be based on completeness, representativeness and up-to-date datasets, however none of the studies justified such choices. Regarding the monetary valuation, $\mathrm{CO}_{2}$ eq. savings are valuated differently showing wide variation in prices such as the hypothetical carbon tax (10 Euro/ton, Winterstetter et al., 2015), the social cost of carbon (20 Euro/ton, Tol, 2008), and the EU Emission Trading Scheme (40 Euro/ton, EU, 2007). Even wider variation is notable for the prices of incentives for renewable energy production such as the green certificate (108-117 Euro/ MWh) in Belgium (Danthurebandara et al., 2015c; Van Passel et al., 2013) and the renewable obligation certificate (542 Euro/MWh) in Scotland (Ford et al., 2013).

\subsubsection{Marketability and market prices}

Most of the studies $(n=13)$ assume the marketability of materials that they plan to recover and valorize. However, specific market quality requirements are seldom mentioned, and that all recovered and valorized materials are assumed to be saleable. There are also some studies that account for marketability and market price though preliminary discussions with potential buyers. Examples include plantation owners for the soil residues as fertilizers (Zhou et al., 2015) and construction companies for plasma gasification residue as construction aggregates (Danthurebandara et al., 2015c; Van Passel et al., 2013). However, there are also studies that have contradictory assumptions. For example, instead of the production of construction aggregates, Winterstetter et al. (2015) considered the re-landfilling of plasma gasification residue, arguing that such a valorization process has not gone beyond laboratory tests. Moreover, none of the studies considers the broader market dynamics of supply and demand upon the introduction of exhumed materials to the market competing with primary sourced materials and more high-quality secondary resources obtained from e.g. source separation programs.

\subsubsection{Economic indicator}

Studies perform either direct cash flow $(n=7)$ or discounted cash flow $(n=8)$ analysis. For the former, it follows that the studies consider small landfill size with high LFM processing capacity, leading to a project duration of about a year. For the latter, project duration is much longer, from 3 to 20 years, in which the time value of money has to be considered (Brealy et al., 2011). The discount rate varies from $3 \%$ to $15 \%$, depending on if public or private financing is considered, respectively. In essence, the project duration and type of financing constitute a downplaying of the value of future revenues and avoided costs, in comparison to the initial investments accounting for higher risks.

\subsubsection{Uncertainty/sensitivity analysis}

From the previous sections, several possible variations are discussed along the LFM value chain processes (i.e. separation, thermal treatment and residue management), as well as in other aspects such as waste composition, externalities and some general assumptions (Table 2). These correspond to the uncertainties that occur in scenario building (scenario uncertainties) and data gathering (parameter uncertainties), which have to be properly addressed for all systems analyses, in general (Clavreul et al., 2012; Huijbregts et al., 2003).

Despite the abovementioned uncertainties, more than half of the studies $(n=8)$ have not performed any parametric uncertainty or sensitivity analyses, of which the majority $(n=6)$ have not considered even any scenario alternatives but instead just a single scenario for a specific LFM project. For the rest of the studies, sensitivity analysis is 
TABLE 2: Overview of uncertainties in the economic assessment of landfill mining.

\begin{tabular}{|c|c|c|c|c|c|c|}
\hline & General & $\begin{array}{l}\text { Waste } \\
\text { composition }\end{array}$ & Separation & $\begin{array}{l}\text { Thermal } \\
\text { treatment }\end{array}$ & $\begin{array}{l}\text { Further valorization/ } \\
\text { residue management }\end{array}$ & Externalities \\
\hline $\begin{array}{l}\text { Scenario } \\
\text { uncertainties }\end{array}$ & $\begin{array}{l}\text { Inclusion/ exclu- } \\
\text { sion of reference } \\
\text { scenario }\end{array}$ & $\begin{array}{l}\text { Type of landfill } \\
\text { waste inclusion/ } \\
\text { exclusion of ha- } \\
\text { zardous waste }\end{array}$ & \multicolumn{3}{|c|}{$\begin{array}{l}\text { Technology choice (conventional to advanced technology) } \\
\text { - Internal or external organizational arrangement } \\
\text { - Marketability of secondary materials and energy (substitution: } \\
\text { full, partial, no market) }\end{array}$} & $\begin{array}{l}\text { Inclusion/ } \\
\text { exclusion of } \\
\text { environmental } \\
\text { and social costs } \\
\text { and benefits/ } \\
\text { revenues }\end{array}$ \\
\hline $\begin{array}{l}\text { Parameter } \\
\text { uncertainties }\end{array}$ & $\begin{array}{l}\text { Origin of costs/ } \\
\text { price data (where } \\
\text { and when) } \\
\text { - Amount of lea- } \\
\text { chate and landfill } \\
\text { gas } \\
\text { Discount rate }\end{array}$ & $\begin{array}{l}\text { Amount in terms } \\
\text { of waste fraction } \\
\text { or chemical } \\
\text { composition }\end{array}$ & $\begin{array}{l}\text { Separation effi- } \\
\text { ciencies } \\
\text { Material market } \\
\text { prices }\end{array}$ & $\begin{array}{l}\text { Energy recovery } \\
\text { efficiencies } \\
\text { - Energy market } \\
\text { prices }\end{array}$ & $\begin{array}{l}\text { Material market } \\
\text { prices }\end{array}$ & $\begin{array}{l}\text { Values of envi- } \\
\text { ronmental and } \\
\text { social costs and } \\
\text { benefits/revenues }\end{array}$ \\
\hline
\end{tabular}

more commonly performed, that is, either alone $(n=2)$ or in combination with uncertainty analysis $(n=5)$. About the same share of studies have performed either global sensitivity analysis $(n=4)$ and local sensitivity analysis $(n=3)$. This uncommon practice of performing uncertainty and sensitivity analyses indicates that the majority of the studies lack information on the robustness of their provided results, hence posing questionable usefulness and validity of fulfilling their intended objectives. Poor uncertainty management may lead to faulty decision support with missing risks information that is related to the net performance of LFM, as well as misunderstanding the principles of performance of LFM with the lack of systematic identification of its main economic drivers.

\subsection{Synthesis of main findings and related critica- lities}

Despite the unique conditions and considerations of individual studies, it can be generalized that LFM is a challenging business venture based on the reported net economic performances. Only a few of the studies are profitable $(n=2)$, while the rest are either not profitable $(n=7)$ or potentially profitable $(n=6)$. The net economic outcome of the studies ranges from a net deficit of $-€ 112$ to a net profit of $+€ 67$. Appendix $A$ gives individual study results that are temporally (GDP deflator) and geographically (purchasing power parity) harmonized.

A main reason for reviewing the findings of previous case studies is to identify reoccurring conditions and settings of importance for the feasibility of a project, thereby contributing to the common knowledge building of a concept or strategy. However, when it comes to LFM, such a synthesis is difficult, due to a general lack of transparency regarding case-specific conditions, and different procedures for the way in which the projects and their different processes have been aggregated and modelled (Sections 3.2-3.3). In most of the case studies, for instance, the LFM value chain is depicted and modelled only in terms of main processes (e.g. excavation and sorting, waste-to-material and waste-to-energy), while the contributions from underlying factors in terms of the numerous parameters that build up each of these processes remain unknown, or at least not systematically accounted for. In addition, many of these processes and parameters are highly connected throughout the LFM process chain, and such interactions or combinational effects often have a significant impact on the economic performance of a project. This treatment of the process chain as a series of black boxes makes it difficult to develop any deeper understanding of what builds up the economy in the different LFM projects, and limits the identification of reoccurring performance drivers to some highly aggregated cost and revenue items, Figure 4.

For several methodological reasons discussed in previous sections, even the interpretation of this type of highly aggregated and superficial information about commonly reported LFM performance drivers should be done with caution. This is because each LFM project is uniquely designed in terms of its site, project set-up and system level conditions and, without a clear record of such settings (as in many of the reviewed case studies), conclusions about the general significance of a certain performance driver might be misleading. For instance, the different case studies involve different approaches to the treatment of combustibles exhumed from the landfills, and this has an overarching impact on the economy of the projects. In cases where such fuel is sent to external waste-to-energy plants, process-related (e.g. excavation and separation) and material flow-related (e.g. transportation and disposal) cash flows are often reported as main cost items. Although such costs remain important in projects involving internal thermal treatment of the extracted combustibles, capital investments and operational expenditures related to the (new) waste-to-energy plant then typically dominate the cost profile. In addition, revenues from energy sales only become applicable for such project set-ups in which the combustibles are thermally treated internally.

Also, when it comes to the reported performance drivers in terms of revenues, drawing conclusions of general relevance for the LFM area is somewhat difficult. For instance, virtually all of the case studies report revenues from recovered materials (which are almost exclusively metals) as an important revenue, while indirect benefits of a LFM project in terms of the value of reclaimed land and landfill void space, or avoided landfill aftercare costs, are less frequently identified as main drivers. However, this does not mean that such indirect benefits are not important for the economic outcome of a LFM project, but rather that the case studies often have involved landfills with no or low aftercare costs situated in locations with relatively low land values and needs for new landfill void space. This 


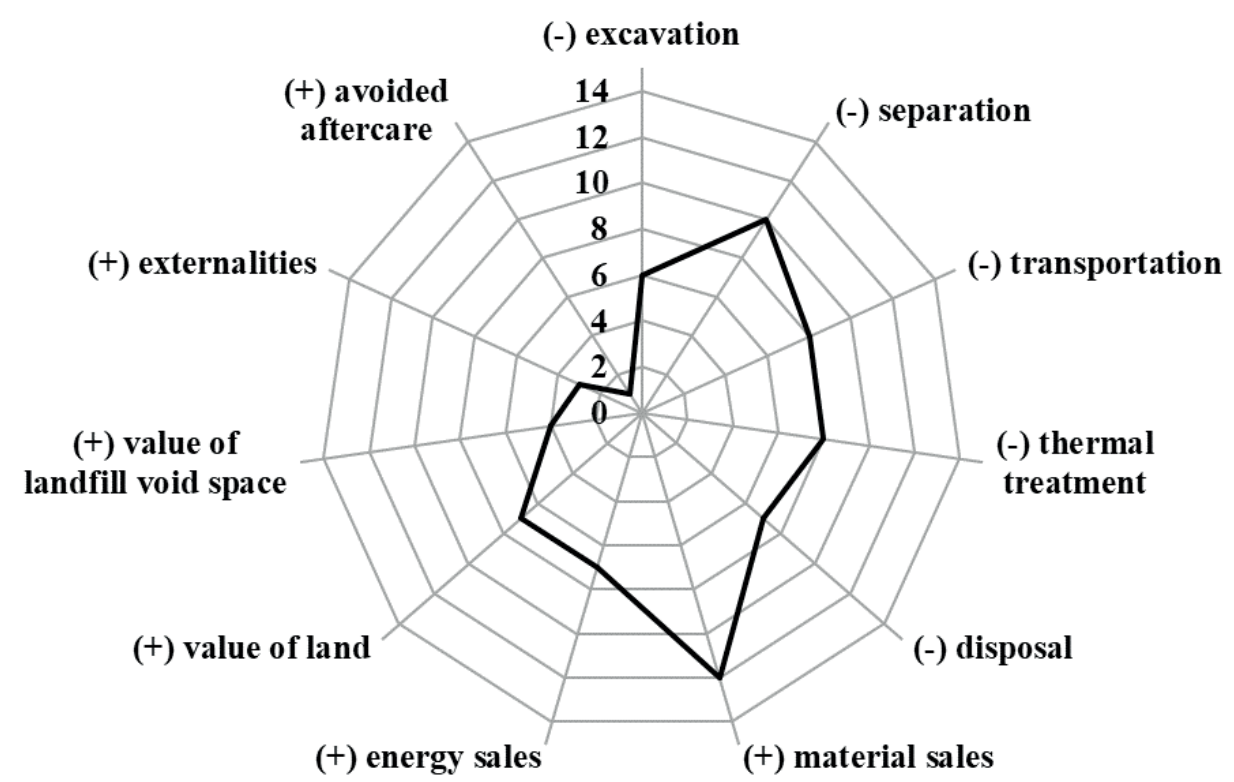

FIGURE 4: Reported economic performance drivers of LFM in the reviewed studies $(n=15)$ in terms of the top three main cost $(-)$ and revenue (+) items. However, due to the differences in the LFM cases and the economic assessment methods used, interpretation should be done with caution. See text for further explanation.

inability to address the importance of sitespecific conditions (e.g. material composition and aftercare needs) and other local settings (needs and values for land and landfill void space) for the economy of LFM projects is an inherent characteristic of the reviewed studies due to their focus on assessing only one case.

\subsection{Usefulness and validity of selected studies and recommendations for future assessments}

One main reason that most of the reviewed studies $(n=9)$ only provide superficial knowledge on what builds up the economic performance of LFM is that they are decision-oriented, as shown in Figure 5 . Thereby, they primarily aim to forecast the net outcome of conducting LFM in a certain landfill site $(n=6$, case study-specific, Category $A)$ or within a wider geographical scope $(n=3$, generic, Category $\mathrm{C}$ ). Both of these analyses aim to produce knowledge that is, indeed, essential for supporting investment decisions on both the project and regional levels (Finnveden and Moberg, 2005; Swarr et al., 2011). However, for emerging concepts such as LFM with a lack of real-life projects and records of accomplishment, the validity of the results obtained from such feasibility assessments can be questioned. For instance, current knowledge deficits about the different processes of the LFM value chain are typically addressed using secondary data from the sorting and recovery of other waste (e.g. fresh MSW) or experiences from small-scale (laboratory) tests (Section 3.2). Not only is the applicability of such data to the large-scale processing of landfilled waste unknown, but also most studies assume that the extracted materials and energy resources will be marketable (Section 3.3.5). Although such inherent knowledge deficits are inevitable for any emerging concept (Clavreul et al., 2012; Hellweg and Milà i Canals, 2014; Martinez-Sanchez et al., 2015), a major concern here is that most of the studies leave them unaccounted for (Section 3.3.5), and hence, their effect on the robustness of the results is unknown. Consequently, landfill owners, project managers, LFM contractors, investors and policy-makers are prone to making decisions based on results with large implicit, or even neglected, information on the economic risks. For instance, if the generally employed assumption that the extracted materials and energy sources will be readily accepted on existing markets is not true (Johansson et al., 2017), this will have significant implications for the economic feasibility of any LFM initiative.

In essence, we are not yet in a position to make this type of profitability claim regarding LFM, not on the project level (Category A) and certainly not on the regional scale (Category C). Before such assessments can be made with any trustworthiness, extensive and applied research is needed to address key issues such as what resources can be extracted from landfills, at what quality levels, and under what conditions they will be accepted on existing markets (Krook et al., 2019). In order to develop such knowledge, there is no alternative than to go from the often-seen laboratory studies to well-planned pilot studies in which the efficiency, capacities and performance of different separation, upcycling and recovery technologies are developed and monitored on a scale comparable to real-life projects. If any stakeholder wants even so to forecast the economic outcome of a specific project or estimate the economic potential of implementing LFM in a region, it is strongly recommended that this be done by employing existing scenario and parameter uncertainty analysis methods. As demonstrated by some studies of project assessments (Danthurebandara et al., 2015c; Frändegård et al., 2015; Van Passel et al., 2013; Winterstetter et al., 2015), such an analytical approach makes it possible to provide more fair feasibility claims. Instead of providing a single (but highly 
case study-specific

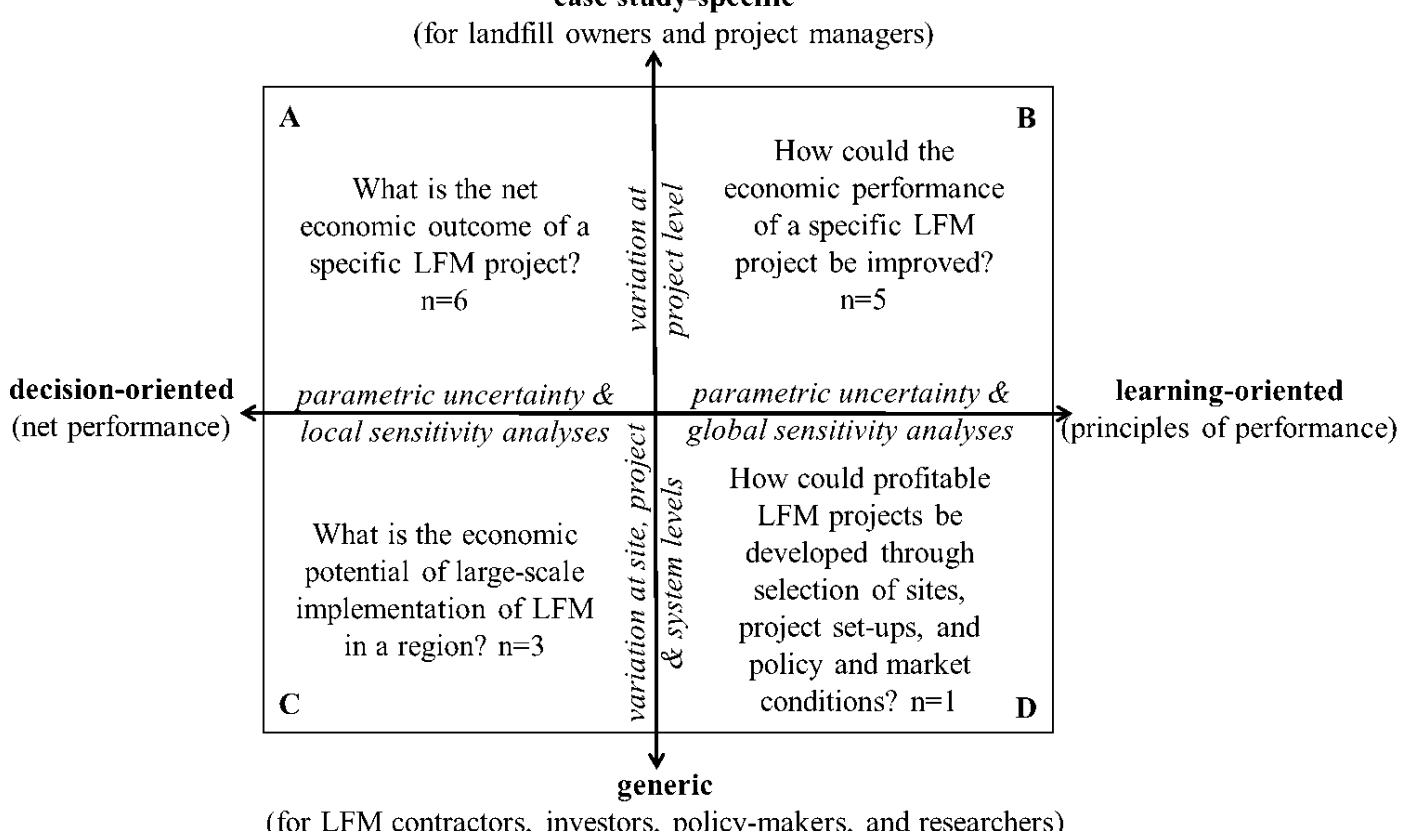

(for LFM contractors, investors, policy-makers, and researchers)

FIGURE 5: The categorization of the selected studies $(n=15)$ in terms of their perceived usefulness. However, given the validity concerns of the results obtained, their usefulness is only partially, if not at all, fulfilled. See text for further explanation.

uncertain) value, it derives a wide range of plausible outcomes in which the implications of current knowledge deficits are explicit.

In order to guide LFM research and knowledge development towards key challenges and potential solutions for cost-efficiency, learning-oriented studies are necessary (Fleischer et al., 2005; Krook et al., 2019; Wender et al., 2014). Several features make such studies distinctively different from decisionoriented studies. To start with, learning-oriented assessments go beyond the intention to obtain an accurate estimate of the net economic outcome of a certain case, and rather aim to provide strategic guidance on how the economic performance can be improved, and to determine what type of knowledge is essential for developing such a project. This change in perspective has some major implications for how to design and execute economic assessments of LFM. In order to account for current empirical constraints and knowledge gaps, an explorative approach is needed (Voinov et al., 2016; Wender et al., 2014), in which multiple possibilities and scenarios are simultaneously assessed to scope in implications of different site-specific settings, choices of processing lines and technologies, and policy and market conditions. Another key characteristic of learning-oriented assessments is that the collection of data for different processes and parameters aims to cover the range of possible variation, both in terms of stochastic and epistemological uncertainties, rather than to obtain, as in many decision-oriented studies, a single (but highly uncertain) value. To handle such wide variations on both the scenario and parameter levels, the employment of systematic uncertainty and sensitivity analyses methods is key (Ferretti et al., 2016; Saltelli and Annoni, 2010). Not only do such methods make it possible to explicitly account for the uncertainties in the results, they also enable fine-grained assessments of the processes, parameters and interactions among them that jointly build up the net economic outcome of LFM.

Several of the reviewed studies can be categorized as learning-oriented in the sense that their main objective is to discover what builds up the net economic performance of conducting LFM in a specific landfill site $(n=5$, case study-specific, Category B), or within a wider geographical scope ( $n=1$, generic, Category D). However, one major limitation of these studies is that they typically only involve a few scenarios in which some of the conditions and settings at the project set-up level are explored. For instance, technical options are limited to one set of separation and thermal treatment processes. Further, project organization is only considered as a certain process, which is either internal or external to the project (Section 3.1). In order to better scope in key challenges and potential solutions, it is necessary to consider a wider variety of options to technically and organizationally set up LFM projects. Moreover, possible variations and choices related to the landfill site and surrounding system levels are seldom explored. On the generic or regional level, the assessment of such variations is a necessity to identify which landfills are suitable for mining and how different policy and market environments influence the economics of such projects. However, even in case-specific assessments, an openness to different alternatives and conditions on these levels is useful, given the often early stage of development and thus huge knowledge deficits regarding such matters as the landfill composition, and the implications of various policies and market conditions. Such exploration of multiple scenarios can be done through the integration of existing knowledge from previous case studies and through participatory scenario development, in which a wider array of possibilities is 
co-created with different experts belonging to the different parts and processes of the LFM value chain (Voinov et al., 2016; Wender et al., 2014).

When handling uncertainties, several of the learning-oriented studies performed parametric uncertainty analysis. However, toonarrow ranges of variation are typically used that mainly cover natural or stochastic variations in the capacity and efficiency of conventional processes, while knowledge-related or epistemic uncertainties in the processing and recovery of previously landfilled waste are seldom addressed. For instance, the stochastic uncertainty related to the separation efficiency of processing fresh MSW is commonly accounted for in such case studies, but not the presumably much larger epistemic uncertainty related to the expected differences in process performance when the input is excavated LFM waste. A direct consequence of this in practice is that there is a risk that the importance of different processes and parameters for the economic performance of LFM will be underestimated. In addition, the quality of recovered materials (whether they have reached market quality standards) and their corresponding marketability (whether there is a market demand for such materials recovered from landfills) also entail huge epistemic uncertainties that are virtually never addressed. Such factors may nevertheless, have significant implications for the economic performance of LFM. Stochastic and epistemic uncertainties are typically addressed by collecting ranges of values and developing probability and possibility distributions together with the respective experts (Clavreul et al., 2013; Lacirignola et al., 2017).

When it comes to the analysis of critical conditions and factors for economic performance, most of the studies use local sensitivity analysis or one-at-a-time sensitivity analysis, in which parameters changes are accounted for individually, rather than simultaneously. Such a method, however, is unsystematic in revealing the important economic drivers, primarily because of its inability to address the interrelations among different processes and parameters (Ferretti et al., 2016; Saltelli and Annoni, 2010). The use of this sensitivity analysis method often leads to the processes and parameters downstream in the LFM value chain being identified as the most critical for the economic outcome, while the fact that their importance is rather a consequence of the realization and interactions with upstream parameters is missed. To take a very simple example, several of the studies conclude that (increasing) raw material prices are one of the most important drivers for increasing the material revenues from LFM, and the studies emphasize the need for exogenous changes or specific policy instruments to stimulate such development. However, the net material revenue that can be obtained is determined rather by the specific interrelations between the content of different materials in the landfill, the costs and efficiency of extracting them into well-defined and marketable material categories, and (to a significantly lesser extent) plausible variations in raw material prices. Uncovering such interrelations thus leads in a totally different direction, in which potential measures to improve the economic performance involve the selection of suitable and more high-grade landfills for mining, and the development of tailored pro- cessing and sorting lines, rather than calling for policy and market interventions that influence raw material prices. One way to systematically reveal such interrelations is by performing both first-order and higher-order variancebased global sensitivity analyses, in which both the direct and combinational economic effects of various conditions, settings and parameters are simultaneously assessed (Saltelli et al., 2010). In practice, extensive data collection must be carried out in order to achieve multiple scenario development. In addition, such analyses are mathematically demanding in terms of modelling design and execution. In the field of LFM, Laner et al. (2016) performed a learningoriented study of the climate impact assessment of LFM in Europe. It employed multiple scenario development that accounted for variations occurring on the site, project and system levels, together with a global sensitivity analysis, which may be one of the bases for future economic assessment of LFM. In general, learning-oriented studies are expected to provide knowledge that can aid in developing a systematic overview of how different conditions, settings and parameters, as well as their interrelations, contribute to the net outcome. Consequently, the focus should be directed to where more learning is demanded. This will reveal what is potentially important and what is not, thereby facilitating priority-setting in terms of where investment into research and knowledge development should be directed.

LFM is an investment-intensive undertaking and strategic guidance for future projects is necessary. One fundamental question is which landfill site to prioritize to exemplify economically favorable projects. In this regard, generic and learning-oriented studies (Category $D$ ) can be used to determine strategic locations for future pilot-scale and (eventually) large-scale project implementations. To direct individual LFM projects in terms of technical and project organizational set-up, case-study specific and learning-oriented studies (Category B) can be used, showing complementarity of approaches. In this way, more practical knowledge and primary sourced data will become available, strengthening in this way the results of generic studies. With widely accepted conclusions that reveal the true economic potential of LFM, further development of favorable policy and market environments can be advised for more cost-efficient LFM projects in the future.

\section{CONCLUSIONS}

A total of 15 studies have been examined in this review, which quantitatively assessed the economic potential of LFM. The majority of the studies are case study-specific, with a decision-oriented type of application. This accounted for individual cases with quite varied LFM project descriptions, and considered scenarios classified at the site, project and system levels. Apparent scenario and parameter uncertainties were highlighted and acknowledged to be inherent to the emerging character of LFM, with the inevitable use of secondary data sources, or primary sources that are based on laboratory to pilot-scale tests. In this regard, transparent descriptions of goal and scope, data inventory and estimations, and model assumptions are called for. These are typical recommendations as sta- 
ted in existing method guidelines (ISO, 2006a, 2006b; Swarr et al., 2011), but they remain unaddressed in the following LFM studies, and in most of the current systems analysis carried out in the field of waste management (Astrup et al., 2015; Laurent et al., 2014a, 2014b; Martinez-Sanchez et al., 2015). Apart from transparency, subsequent management of these uncertainties must be addressed to ensure the usefulness and validity of study results.

Moreover, this review highlights that economic assessments, obtained through a learning-oriented approach, can be used not just to obtain the net performance, but also to understand the principles of performance and improve current knowledge levels for future LFM project implementation. In dealing with LFM with large knowledge deficits, it is highly recommended that more extensive and applied research must be carried out. Such LFM initiatives can be guided by learning-oriented approach in terms of site selection (Which landfill site is suitable for mining?), project implementation (Which technological set up and project organizational set up are preferable?), and system setting (Which policy and market conditions are favorable?) towards the development of cost-efficient LFM projects. In this case, explorative scenario development can be used by accounting multiple variations at site, project, and system levels. Subsequently, the related uncertainties and their respective importance can be accounted for by performing parameter uncertainty analysis and global sensitivity analysis. Furthermore, with the broader scope of assessment and granular analysis of parameter importance, the overarching key potentials and challenges of LFM can systematically be identified. Hence, future LFM research prioritization can be guided. For instance, according to their relative importance, specific parameter improvements can be focused on, individually or in combination, such as better separation efficiency or energy conversion efficiency at the project level, or more favorable market standards and prices as well as lower taxes and gate fees at the system level. In consideration of LFM as an investment-intensive undertaking, such strategic guidance through a learningoriented economic assessment can be beneficial in harnessing its economic potential even at an emerging phase of development.

\section{ACKNOWLEDGEMENTS}

This study has received funding from the European Training Network for Resource Recovery Through Enhanced Landfill Mining (NEW-MINE, Grant Agreement No 721185) under the European Union's EU Framework Programme for Research and Innovation Horizon 2020.

\section{REFERENCES}

Ahlroth, S., Nilsson, M., Finnveden, G., Hjelm, O., Hochschorner, E., 2011. Weighting and valuation in selected environmental systems analysis tools e suggestions for further developments. J Clean Prod 19, 145-156. https://doi.org/10.1016/j.jclepro.2010.04.016

Association Bilan Carbone, 2007. Release of version 8.2 of Bilan Carbone ${ }^{\circledR}$ [WWW Document]. URL https://www.associationbilancarbone.fr/nouveautes-version-8-2-bilan-carbone/ (accessed 6.5.19).
Astrup, T.F., Tonini, D., Turconi, R., Boldrin, A., 2015. Life cycle assessment of thermal Waste-to-Energy technologies: Review and recommendations. Waste Manag 37, 104-115. https://doi. org/10.1016/j.wasman.2014.06.011

Bosmans, A., Vanderreydt, I., Geysen, D., Helsen, L., 2013. The crucial role of Waste-to-Energy technologies in enhanced landfill mining: A technology review. J Clean Prod 55, 10-23. https://doi. org/10.1016/j.jclepro.2012.05.032

Brealy, R.A., Myers, S.C., Allen, F., 2011. Net Present Value and Other Investment Criteria, in: Principles of Corporate Finance. The McGraw-Hill/Irwin, New York, pp. 101-115.

Burlakovs, J., Kriipsalu, M., Klavins, M., Bhatnagar, A., Vincevica-Gaile, Z., Stenis, J., Jani, Y., Mykhaylenko, V., Denafas, G., Turkadze, T., Hogland, M., Rudovica, V., Kaczala, F., Rosendal, R.M., Hogland, W., 2017. Paradigms on landfill mining: From dump site scavenging to ecosystem services revitalization. Resour Conserv Recycl 123, 73-84. https://doi.org/10.1016/j.resconrec.2016.07.007

Clavreul, J., Guyonnet, D., Christensen, T.H., 2012. Quantifying uncertainty in LCA-modelling of waste management systems. Waste Manag 32, 2482-2495. https://doi.org/10.1016/J.WASMAN.2012.07.008

Clavreul, J., Guyonnet, D., Tonini, D., Christensen, T.H., 2013. Stochastic and epistemic uncertainty propagation in LCA. Int $\mathrm{J}$ Life Cycle Assess 18, 1393-1403. https://doi.org/10.1007/s11367-013-0572-6

Confederation of European Waste-to-Energy Plants, 2017. Landfill taxes and bans [WWW Document]. URL http://www.cewep.eu/wpcontent/uploads/2017/12/Landfill-taxes-and-bans-overview.pdf (accessed 3.1.19).

Cossu, R., Williams, I.D., 2015. Urban mining: Concepts, terminology, challenges. Waste Manag 45, 1-3. https://doi.org/10.1016/j.wasman.2015.09.040

Cucurachi, S., Giesen, C. Van Der, Guinée, J., 2018. Ex-ante LCA of emerging technologies. Procedia CIRP 69, 463-468. https://doi. org/10.1016/j.procir.2017.11.005

Damigos, D., Menegaki, M., Kaliampakos, D., 2016. Monetizing the social benefits of landfill mining: Evidence from a Contingent Valuation survey in a rural area in Greece. Waste Manag 51, 119-129. https://doi.org/10.1016/j.wasman.2015.12.012

Danthurebandara, M., Van Passel, S., Machiels, L., Van Acker, K., $2015 a$. Valorization of thermal treatment residues in Enhanced Landfill Mining: Environmental and economic evaluation. J Clean Prod 99, 275-285. https://doi.org/10.1016/j.jclepro.2015.03.021

Danthurebandara, M., Van Passel, S., Van Acker, K., 2015b. Environmental and economic assessment of "open waste dump" mining in Sri Lanka. Resour Conserv Recycl 102, 67-79. https://doi. org/10.1016/j.resconrec.2015.07.004

Danthurebandara, M., Van Passel, S., Vanderreydt, I., Van Acker, K., 2015c. Assessment of environmental and economic feasibility of Enhanced Landfill Mining. Waste Manag 45, 434-447. https://doi. org/10.1016/j.wasman.2015.01.041

Ecoinvent, 2010. Ecoinvent Version 2 [WWW Document]. URL https:// www.ecoinvent.org/database/older-versions/ecoinvent-version-2/ecoinvent-version-2.html (accessed 6.5.19).

Ellen MacArthur Foundation, 2013. Towards the Circular Economy [WWW Document]. URL http://circularfoundation.org/sites/default/files/tce_report1_2012.pdf (accessed 12.7.18).

EU, 2007. The EU Emissions Trading System (EU ETS) [WWW Document]. URL https://ec.europa.eu/clima/sites/clima/files/factsheet_ets_en.pdf (accessed 6.5.19).

European Commission-Joint Research Center, 2010. International Reference Life Cycle Data System (ILCD) Handbook - Specific guide for Life Cycle Inventory data sets, 1st ed. Publications Office of the European Union, Luxembourg.

European Enhanced Landfill Mining Consortium, 2019. EURELCO - EU Funded Landfill Mining Projects [WWW Document]. URL https:// eurelco.org/projects/ (accessed 4.7.19).

European Parliament, 2018. Answer to Question No E-003580/18 [WWW Document]. URL http://www.europarl.europa.eu/doceo/ document/E-8-2018-003580-ASW_EN.html?redirect\#ref2 (accessed 3.15.19).

Financial Times, 2018. Europe's half a million landfill sites potentially worth a fortune [WWW Document]. URL https://www.ft.com/ content/0bf645dc-d8f1-11e7-9504-59efdb70e12f (accessed 4.8.19).

Finnveden, G., Moberg, Å., 2005. Environmental systems analysis tools - an overview. J Clean Prod 13, 1165-1173. https://doi. org/10.1016/J.JCLEPRO.2004.06.004 
Fleischer, T., Decker, M., Fiedeler, U., 2005. Assessing emerging technologies-Methodological challenges and the case of nanotechnologies. Technol Forecast Soc Change, New Horizons and Challenges for Future-Oriented Technology Analysis: The 2004 EU-US Seminar 72, 1112-1121. https://doi.org/10.1016/j.techfore.2004.10.005

Ford, S., Warren, K., Lorton, C., Smithers, R., Read, A., Hudgins, M., 2013. Feasibility and Viability of Landfill Mining and Reclamation in Scotland

Frändegård, P., Krook, J., Svensson, N., 2015. Integrating remediation and resource recovery: On the economic conditions of landfill mining. Waste Manag 42, 137-147. https://doi.org/10.1016/j.wasman.2015.04.008

German Federal Environmental Agency, 2013. Prozessorientierte Basisdaten für Umweltmanagement-Instrumente (ProBas) [WWW Document]. URL http://www.probas.umweltbundesamt.de/php/ index.php (accessed 6.5.19).

Guinée, J., 2016. Life Cycle Sustainability Assessment: What Is It and What Are Its Challenges?, in: Taking Stock of Industrial Ecology. Springer International Publishing, Cham, pp. 45-68. https://doi. org/10.1007/978-3-319-20571-7_3

Heijungs, R., Settanni, E., Guinée, J., 2013. Toward a computational structure for life cycle sustainability analysis: unifying LCA and LCC. Int J Life Cycle Assess 18, 1722-1733. https://doi. org/10.1007/s11367-012-0461-4

Hekkert, M.P., Suurs, R.A.A., Negro, S.O., Kuhlmann, S., Smits, R.E.H.M., 2007. Functions of innovation systems: A new approach for analysing technological change. Technol Forecast Soc Change 74 413-432. https://doi.org/10.1016/j.techfore.2006.03.002

Hellweg, S., Milà i Canals, L., 2014. Emerging approaches, challenges and opportunities in life cycle assessment. Science 344, 1109-13. https://doi.org/10.1126/science.1248361

Hermann, R., Baumgartner, R.J., Sarc, R., Ragossnig, A., Wolfsberger T., Eisenberger, M., Budischowsky, A., Pomberger, R., 2014. Landfill mining in Austria: foundations for an integrated ecological and economic assessment. Waste Manag Res 32, 48-58. https://doi. org/10.1177/0734242X14541168

Hermann, R., Baumgartner, R.J., Vorbach, S., Wolfsberger, T., Ragossnig, A., Pomberger, R., 2016. Holistic assessment of a landfill mining pilot project in Austria: Methodology and application. Waste Manag Res 34, 646-657. https://doi.org/10.1177/0734242X16644517

Hernandez Parrodi, J.C., Hollen, D., Pomberger, R., 2018. Fine fractions from landfill mining : Potential and main challenges to overcome. Detritus 19-29. https://doi.org/10.31025/2611-4135/2018.13689

Hernández Parrodi, J.C., Höllen, D., Pomberger, R., 2018. Potential and main challenges for material and energy recovery from fine fractions of landfill mining: A critical review. Detritus 3 (1) 19-29. https://doi.org/10.31025/2611-4135/2018.13689

Hogland, M., Āriṇa, D., Kriipsalu, M., Jani, Y., Kaczala, F., Luís de Sá Salomão, A., Orupõld, K., Pehme, K.-M., Rudoviča, V., Denafas, G. Burlakovs, J., Vincēviča-Gaile, Z., Hogland, W., Hogland williamhogland, W., 2018. Remarks on four novel landfill mining case studies in Estonia and Sweden. J Mater Cycles Waste Manag 20, 13551363. https://doi.org/10.1007/s10163-017-0683-4

Hogland, W., Hogland, M., Marques, M., 2010. Enhanced landfill mining: material recovery, energy utilisation and economics in the EU (Directive) perspective. ELFM Symp landfill Min Transit to Sustain Mater Manag 209-222.

Hölzle, I., 2019. Analysing material flows of landfill mining in a regional context. J Clean Prod 207, 317-328. https://doi.org/10.1016/j. jclepro.2018.10.002

Huijbregts, M.A.J., Gilijamse, W., Ad M. J. Ragas, Reijnderst, L., 2003. Evaluating Uncertainty in Environmental Life-Cycle Assessment. A Case Study Comparing Two Insulation Options for a Dutch OneFamily Dwelling. https://doi.org/10.1021/ES020971+

ISO, 2006a. International standard ISO 14040:2006 - Environmental management -- Life cycle assessment -- Principles and framework.

ISO, 2006b. International standard ISO 14044:2006 - Environmental management -- Life cycle assessment -- Requirements and guidelines.

Johansson, N., Krook, J., Eklund, M., 2017. The institutional capacity for a resource transition-A critical review of Swedish governmental commissions on landfill mining. Environ Sci Policy 70, 46-53. https://doi.org/10.1016/j.envsci.2017.01.005

Johansson, N., Krook, J., Eklund, M., 2012. Transforming dumps into gold mines. Experiences from Swedish case studies. Environ Innov Soc Transitions 5, 33-48. https://doi.org/10.1016/j. eist.2012.10.004
Jones, P.T., Geysen, D., Tielemans, Y., Passel, S. Van, Pontikes, Y., Blanpain, B., Quaghebeur, M., Hoekstra, N., 2013. Enhanced Landfill Mining in view of multiple resource recovery: a critical review. J Clean Prod 55, 45-55. https://doi.org/10.1016/j.jclepro.2012.05.021

Kieckhäfer, K. Breitenstein, A. Spengler, T.S., 2017. Material flow-based economic assessment of landfill mining processes. Waste Manag 60, 748-764. https://doi.org/10.1016/j.wasman.2016.06.012

Krook, J., Baas, L., 2013. Getting serious about mining the technosphere: a review of recent landfill mining and urban mining research. https://doi.org/10.1016/j.jclepro.2013.04.043

Krook, J., Johansson, N., Frändegård, P., 2015. Landfill Mining: On the Potential and Multifaceted Challenges for Implementation, in: Taherzadeh, Mohammad Richards, T. (Ed.), . CRC Press, pp. 313330. https://doi.org/10.1201/b18680-15

Krook, J., Jones, P.T., Van Passel, S., 2018a. Why Enhanced Landfill Mining (ELFM) needs to be politically acknowledged to facilitate sustainable management of European landfills. Policy Brief, EU Training Network for Resource Recovery through Enhanced Landfill Mining (NEW-MINE) [WWW Document]. URL https://kuleuven.sim2.be/wp-content/uploads/2018/11/NEW-MINE-pdf-PBNov-2018.pdf (accessed 3.24.19).

Krook, J., Svensson, N., Eklund, M., 2012. Landfill mining: A critical review of two decades of research. Waste Manag 32, 513-520. https://doi.org/10.1016/j.wasman.2011.10.015

Krook, J., Svensson, N., Van Acker, K., Van Passel, S., 2018b. How to evaluate (enhanced) landfill mining? A critical review of recent environmental and economic assessments, in: 4th Internationa Symposium on Enhanced Landfill Mining, Mechelen, Belgium 5-6 February. pp. 317-332.

Krook, J., Svensson, N., Van Passel, S., Van Acker, K., 2019. What do Recent Assessments Tell Us About the Potential and Challenges of Landfill Mining? Sustain Resour Recover Zero Waste Approaches 267-281. https://doi.org/10.1016/B978-0-444-64200-4.00018-9

Lacirignola, M., Blanc, P., Girard, R., Pérez-López, P., Blanc, I., 2017. LCA of emerging technologies: addressing high uncertainty on inputs' variability when performing global sensitivity analysis. Sci Total Environ 578, 268-280. https://doi.org/10.1016/J.SCITOTENV.2016.10.066

Laner, D., Cencic, O., Svensson, N., Krook, J., 2016. Quantitative Analysis of Critical Factors for the Climate Impact of Landfill Mining. Environ Sci Technol 50, 6882-6891. https://doi.org/10.1021/ acs.est.6b01275

Laurent, A., Bakas, I., Clavreul, J., Bernstad, A., Niero, M., Gentil, E., Hauschild, M.Z., Christensen, T.H., 2014a. Review of LCA studies of solid waste management systems - Part I: Lessons learned and perspectives. Waste Manag 34, 573-588. https://doi.org/10.1016/j. wasman.2013.10.045

Laurent, A., Clavreul, J., Bernstad, A., Bakas, I., Niero, M., Gentil, E., Christensen, T.H., Hauschild, M.Z., 2014b. Review of LCA studies of solid waste management systems - Part II: Methodological guidance for a better practice. Waste Manag 34, 589-606. https:// doi.org/10.1016/j.wasman.2013.12.004

Løvik, A.N., Hagelüken, C., Wäger, P., 2018. Improving supply security of critical metals: Current developments and research in the EU. Sustain Mater Technol 15, 9-18. https://doi.org/10.1016/j. susmat.2018.01.003

Martinez-Sanchez, V., Kromann, M.A., Astrup, T.F., 2015. Life cycle costing of waste management systems: Overview, calculation principles and case studies. https://doi.org/10.1016/j.wasman.2014.10.033

Pinior, B., Firth, C.L., Richter, V., Lebl, K., Trauffler, M., Dzieciol, M., Hutter, S.E., Burgstaller, J., Obritzhauser, W., Winter, P., Käsbohrer, A., 2017. A systematic review of financial and economic assessments of bovine viral diarrhea virus (BVDV) prevention and mitigation activities worldwide. Prev Vet Med 137, 77-92. https://doi.org/10.1016/J. PREVETMED.2016.12.014

Rosendal, R., 2015. The economics of landfill mining - focus on the legth of aftercare, in: Proceedings Sardinia 2015, 15th International Waste Management and Landfill Symposium, S. Margherita Di Pula, Cagliari, Italy. Sardinia.

Saltelli, A., Annoni, P., Azzini, I., Campolongo, F., Ratto, M., Tarantola, S. 2010. Variance based sensitivity analysis of model output. Design and estimator for the total sensitivity index. Comput Phys Commun 181, 259-270. https://doi.org/10.1016/j.cpc.2009.09.018

Saltelli, A., Ratto, M., Andres, T., Campolongo, F., Cariboni, J., Gatelli, D., Saisana, M., Tarantola, S., 2008. Global Sensitivity Analysis: The Primer. John Wiley \& Sons Ltd., Chichester, England. 
Swarr, T., Hunkeler, D., Klopffer, W., Pesonen, H.-L., Ciroth, A., Brent, A., Pagan, R., 2011. Environmental life cycle costing : a code of practice. Society of Environmental Toxicology and Chemistry, Pensacola.

Tol, R.S.J., 2008. The Social Cost of Carbon: Trends, Outliers and Catastrophes. Econ Open-Access, Open-Assessment E-Journal 2, 1. https://doi.org/10.5018/economics-ejournal.ja.2008-25

Van Der Zee, D.J., Achterkamp, M.C., De Visser, B.J., 2004. Assessing the market opportunities of landfill mining. Waste Manag 24, 795804. https://doi.org/10.1016/j.wasman.2004.05.004

Van Passel, S., Dubois, M., Eyckmans, J., De Gheldere, S., Ang, F., Tom Jones, P., Van Acker, K., 2013. The economics of enhanced landfill mining: Private and societal performance drivers. J Clean Prod 55, 92-102. https://doi.org/10.1016/j.jclepro.2012.03.024

Van Vossen, W.J., Prent, O.J., 2011. Feasibility study of sustainable material and energy recovery from landfills in EU, in: Proceedings Sardinia 2011, 13th International Waste Management and Landfill Symposium S. Margherita Di Pula, Cagliari, Italy. Sardinia.

Voinov, A., Kolagani, N., Mccall, M.K., Glynn, P.D., Kragt, M.E., Ostermann, F.O., Pierce, S.A., Ramu, P., 2016. Modelling with stakeholders e Next generation. https://doi.org/10.1016/j.envsoft.2015.11.016

Wagner, T.P., Raymond, T., 2015. Landfill mining: Case study of a successful metals recovery project. Waste Manag 45, 448-457. https://doi.org/10.1016/j.wasman.2015.06.034

Wender, B.A., Foley, R.W., Hottle, T.A., Sadowski, J., Prado-Lopez, V., Eisenberg, D.A., Laurin, L., Seager, T.P., 2014. Anticipatory life-cycle assessment for responsible research and innovation. J Responsible Innov 0. https://doi.org/10.1080/23299460.2014.920121
Winterstetter, A., Laner, D., Rechberger, H., Fellner, J., 2015. Framework for the evaluation of anthropogenic resources: A landfill mining case study - Resource or reserve? Resour Conserv Recycl 96, 1930. https://doi.org/10.1016/j.resconrec.2015.01.004

Wolfsberger, T., Pinkel, M., Polansek, S., Sarc, R., Hermann, R., Pomberger, R., 2016. Landfill mining: Development of a cost simulation model. Waste Manag Res 34, 356-367. https://doi. org/10.1177/0734242X16628980

World Bank, 2016. World Bank Country and Lending Groups - World Bank Data Help Desk [WWW Document]. URL https://datahelpdesk.worldbank.org/knowledgebase/articles/906519-world-bankcountry-and-lending-groups (accessed 3.1.18).

World Bank, 2014. Purchasing Power Parities and the Real Size of World Economies: A Comprehensive Report of the 2011 International Comparison Program. The World Bank. https://doi. org/10.1596/978-1-4648-0329-1

World Economic Forum, 2017. Landfill mining: is this the next big thing in recycling? [WWW Document]. URL https://www.weforum.org/ agenda/2017/06/landfill-mining-recycling-eurelco/ (accessed 4.8.19).

Zanetti, M., Godio, A., 2006. Recovery of foundry sands and iron fractions from an industrial waste landfill. Conserv Recycl 48, 396411. https://doi.org/10.1016/j.resconrec.2006.01.008

Zhou, C., Gong, Z., Hu, J., Cao, A., Liang, H., 2015. A cost-benefit analysis of landfill mining and material recycling in China. Waste Manag 35, 191-198. https://doi.org/10.1016/j.wasman.2014.09.029

\section{APPENDIX A}

Overview of the empirical findings from the selected studies $(n=15)$. The net result is presented as stated in each studies as well as the harmonized values for better cross-country comparison (literature value; harmonized value). Harmonization of values is done using GDP deflator (temporal harmonization) and purchasing power parity (geographical harmonization) conversion factors for 2018. For some studies $(n=2)$, actual values are not explicitly stated that may be intended due to proprietary reasons, but at least, net profitability (positive or negative) can be inferred.

\begin{tabular}{|c|c|c|c|c|c|}
\hline \multirow{2}{*}{$\begin{array}{l}\text { Selected studies } \\
(n=15)\end{array}$} & \multirow{2}{*}{$\begin{array}{l}\text { Landfill characteristics } \\
\text { waste type (W), size } \\
\text { (S), and location (L) }\end{array}$} & \multirow{2}{*}{$\begin{array}{l}\text { Scale of } \\
\text { excavation }\end{array}$} & \multirow{2}{*}{$\begin{array}{c}\text { Net result, } \\
€ / \text { ton of excavated } \\
\text { waste }\end{array}$} & \multicolumn{2}{|c|}{ Economic performance drivers } \\
\hline & & & & Main costs & $\begin{array}{l}\text { Main benefits/ } \\
\text { revenues }\end{array}$ \\
\hline Zanetti \& Godio, 2006 & $\begin{array}{c}\text { W: monolandfill } \\
\text { (foundry) } \\
\text { S: medium }\left(85000 \mathrm{~m}^{2}\right) \\
\text { L: Crescentino landfill, } \\
\text { Italy }\end{array}$ & pilot & $\begin{array}{l}\text { not profitable } \\
\qquad(-3 ;-5)\end{array}$ & $\begin{array}{c}\text { treatment \& re- } \\
\text { landfilling (fines), fuel, } \\
\text { amortization, transpor- } \\
\text { tation, labor }\end{array}$ & $\begin{array}{c}\text { material sales (silica } \\
\text { sands \& iron powder), } \\
\text { value of landfill void } \\
\text { space (mentioned but } \\
\text { not valuated) }\end{array}$ \\
\hline $\begin{array}{l}\text { Van Vossen \& Prent, } \\
2011\end{array}$ & $\begin{array}{c}\text { W: mix MSW-IW } \\
\text { S: small (0.5 Mt) } 60 \\
\text { European landfill sites) } \\
\text { L: Europe }\end{array}$ & hypothetical & $\begin{array}{c}\text { potentially profitable } \\
(-22 \text { to }+1.7 ;-27 \text { to }+2) \\
\text { complete material } \\
\text { separation and sales }\end{array}$ & $\begin{array}{l}\text { separation, transport } \\
\text { on- \& off-site, excava- } \\
\text { tion, unforeseen costs }\end{array}$ & $\begin{array}{l}\text { material sales (metals, } \\
\text { plastics, CDW, stones, } \\
\text { soil), value of landfill } \\
\text { voidspace \& land, } \\
\text { reduction in process } \\
\text { costs of materials, } \\
\text { avoided aftercare costs }\end{array}$ \\
\hline Ford et al., 2013 & $\begin{array}{c}\text { W: MSW } \\
\text { S: medium (1.3 Mt) } \\
\text { L: Scotland }\end{array}$ & hypothetical & $\begin{array}{l}\text { potentially profitable } \\
(-91 \text { to }+33 ;-112 \text { to } \\
+41) \\
\text { WtE int with energy } \\
\text { recovery and sale of } \\
\text { land }\end{array}$ & $\begin{array}{l}\text { separation, excavation, } \\
\text { re-landfilling, WtE int. }\end{array}$ & $\begin{array}{l}\text { green certificate, value } \\
\text { of land, electricity }\end{array}$ \\
\hline Rosendal, 2015 & $\begin{array}{c}\text { W: monolandfill (shred- } \\
\text { der residue) } \\
\text { S: small }(0.3 \mathrm{Mt}) \\
\text { L: Reno Djurs landfill, } \\
\text { Denmark }\end{array}$ & full & $\begin{array}{l}\text { potentially profitable } \\
(-22 \text { to }+20 ;-20 \text { to }+18) \\
\text { w/o re-landfilling tax, } \\
\text { on-site separation, } \\
\text { w/ tax refund, longer } \\
\text { aftercare period (50- } \\
100 \text { yrs) }\end{array}$ & $\begin{array}{l}\text { re-landfilling, sepa- } \\
\text { ration, WtE (incinera- } \\
\text { tion), transportation, } \\
\text { excavation }\end{array}$ & $\begin{array}{l}\text { material sales } \\
\text { (metals), tax refund, } \\
\text { financial provision } \\
\text { refund, value of landfill } \\
\text { voidspace, avoided } \\
\text { aftercare (valuated but } \\
\text { excluded in net result) }\end{array}$ \\
\hline Van Passel et al., 2013 & $\begin{array}{c}\text { W: mix MSW-IW } \\
\text { S: large (16 Mt, } 182 \\
\text { Mt) } \\
\text { L: REMO landfill and } \\
\text { Flanders Region, } \\
\text { Belgium }\end{array}$ & pilot & $\begin{array}{l}\text { potentially profitable } \\
\text { (-unspecified to }+12 \text {; } \\
+15) \\
\text { societal benefit, sale } \\
\text { of land }\end{array}$ & $\begin{array}{l}\text { WtE (incineration), } \\
\text { sorting \& pre-tre- } \\
\text { atment, contingency, } \\
\text { excavation }\end{array}$ & $\begin{array}{l}\text { electricity, material sa- } \\
\text { les (shredder, metals, } \\
\text { slag), value of land }\end{array}$ \\
\hline
\end{tabular}




\begin{tabular}{|c|c|c|c|c|c|}
\hline $\begin{array}{l}\text { Danthurebandara et al., } \\
\text { 2015b }\end{array}$ & $\begin{array}{c}\text { W: MSW } \\
\text { S: medium (1 Mt, } 50 \\
\left.000 \mathrm{~m}^{2}\right) \\
\text { L: open dumpsite, Sri } \\
\text { Lanka }\end{array}$ & hypothetical & $\begin{array}{c}\text { not profitable } \\
(-13 \text { to }-8 ;-16 \text { to- } 10)\end{array}$ & $\begin{array}{l}\text { transportation, WtE, } \\
\text { sorting, re-landfilling }\end{array}$ & $\begin{array}{c}\text { electricity, material sa- } \\
\text { les (metals, RDF, glass } \\
\text { aggregates, glass), } \\
\text { value of land }\end{array}$ \\
\hline $\begin{array}{l}\text { Danthurebandara et al., } \\
\text { 2015c }\end{array}$ & $\begin{array}{c}\text { W: mix MSW-IW } \\
\text { S: large }(16 \mathrm{Mt}, 130 \\
\left.000 \mathrm{~m}^{2}\right) \\
\text { L: REMO landfill, } \\
\text { Belgium }\end{array}$ & pilot & $\begin{array}{l}\text { not profitable } \\
\text { (-unspecified) }\end{array}$ & $\begin{array}{l}\text { WtE (plasma gasifi- } \\
\text { cation) }\end{array}$ & $\begin{array}{l}\text { electricity, calorific } \\
\text { value of RDF, green } \\
\text { certificate }\end{array}$ \\
\hline Frändegård et al., 2015 & $\begin{array}{c}\text { W: MSW } \\
\text { S: small }(0.1 \mathrm{Mt}) \\
\text { L: hypothetical landfill, } \\
\text { Sweden }\end{array}$ & hypothetical & $\begin{array}{c}\text { potentially profitable, } \\
(-14 \text { to }+23 ;-15 \text { to }+25) \\
5 \% \text { probability } \\
\text { w/o re-landfilling tax, } \\
\text { WtE int. }\end{array}$ & $\begin{array}{c}\text { re-landfilling, WtE, } \\
\text { separation, landfill re- } \\
\text { construction, transport }\end{array}$ & $\begin{array}{l}\text { electricity \& heat, } \\
\text { material sales, value } \\
\text { of land }\end{array}$ \\
\hline $\begin{array}{l}\text { Winterstetter et al., } \\
2015\end{array}$ & $\begin{array}{c}\text { W: mix MSW-IW } \\
\text { S: large }(16 \mathrm{Mt}, 130 \\
\left.000 \mathrm{~m}^{2}\right) \\
\text { L: REMO landfill, } \\
\text { Belgium }\end{array}$ & pilot & $\begin{array}{c}\text { not profitable } \\
(-19 \text { to }-12 ;-23 \text { to }-15)\end{array}$ & $\begin{array}{l}\text { WtE, separation, exca- } \\
\text { vation \& storage }\end{array}$ & $\begin{array}{c}\text { electricity, material } \\
\text { sales (metals), avoided } \\
\text { aftercare }\end{array}$ \\
\hline $\begin{array}{l}\text { Wagner \& Raymond, } \\
2015\end{array}$ & $\begin{array}{c}\text { W: monolandfill } \\
\text { (ashfill) } \\
\text { S: large (725 } 700 \mathrm{Mt}) \\
\text { L: Ecomaine landfill, } \\
\text { USA }\end{array}$ & full & $\begin{array}{l}\text { profitable } \\
(+49:+48)\end{array}$ & $\begin{array}{c}\text { separation, excavation, } \\
\text { fuel, labor, mainte- } \\
\text { nance }\end{array}$ & $\begin{array}{l}\text { material sales (me- } \\
\text { tals), value of landfill } \\
\text { voidspace }\end{array}$ \\
\hline Zhou et al., 2015 & $\begin{array}{c}\text { W: MSW } \\
\text { S: small }(0.5 \mathrm{Mt}) \\
\text { L: Yingchun Landfill, } \\
\text { China }\end{array}$ & pilot & $\begin{array}{c}\text { profitable } \\
(+3 \text { to }+29 ;+7 \text { to }+67)\end{array}$ & $\begin{array}{l}\text { excavation, separation, } \\
\text { transportation }\end{array}$ & $\begin{array}{l}\text { electricity, value of } \\
\text { land, recycling soil-like } \\
\text { materials }\end{array}$ \\
\hline Damigos et al., 2016 & $\begin{array}{c}\text { W: MSW } \\
\text { S: small }(0.4 \mathrm{Mt}) \\
\text { L: Polygyros landfill, } \\
\text { Greece }\end{array}$ & pilot & $\begin{array}{l}\text { potentially profitable } \\
(-5.4 \text { to }+170 ;-9 \text { to } \\
+269) \\
\text { socioeconomic costs } \\
\text { \& benefits }\end{array}$ & $\begin{array}{l}\text { socioeconomic costs } \\
\text { (harmful effects of } \\
\text { excavation \& proces- } \\
\text { sing, waste disposal, } \\
\text { etc.), excavation, } \\
\text { separation }\end{array}$ & $\begin{array}{c}\text { socioeconomic } \\
\text { benefits (direct em- } \\
\text { ployment, minimization } \\
\text { of contamination, etc.), } \\
\text { material sales (plastic, } \\
\text { metals) }\end{array}$ \\
\hline $\begin{array}{l}\text { Wolfsberger et al., } \\
2016\end{array}$ & $\begin{array}{c}\text { W: MSW } \\
\text { S: small (0.7 Mt) } \\
\text { L: Ave. Sanitary Land- } \\
\text { fill, Austria }\end{array}$ & pilot & $\begin{array}{l}\text { not profitable } \\
(-40 ;-48)\end{array}$ & $\begin{array}{l}\text { re-landfilling (incl. tran- } \\
\text { sport), separation }\end{array}$ & $\begin{array}{c}\text { material sales (metals, } \\
\text { aggregates) }\end{array}$ \\
\hline Hermann et al., 2016 & $\begin{array}{c}\text { W: MSW } \\
\text { S: small (0.7 Mt) } \\
\text { L: Ave. Sanitary Land- } \\
\text { fill, Austria }\end{array}$ & pilot & $\begin{array}{c}\text { not profitable } \\
(-39 \text { to }-12 ;-47 \text { to }-14)\end{array}$ & $\begin{array}{c}\text { re-landfilling } \\
\text { separation, excavation }\end{array}$ & $\begin{array}{l}\text { value of landfill } \\
\text { voidspace, material } \\
\text { sales (metals) }\end{array}$ \\
\hline Kieckhäfer et al., 2017 & $\begin{array}{c}\text { W: MSW } \\
\text { S: medium }(2.6 \mathrm{Mt}, 270 \\
\left.000 \mathrm{~m}^{2}\right) \\
\text { L: Pohlsche Heide } \\
\text { Landfill, Germany }\end{array}$ & pilot & $\begin{array}{c}\text { not profitable } \\
(-62 \text { to }-35 ;-76 \text { to }-43)\end{array}$ & $\begin{array}{l}\text { WtE (waste incinera- } \\
\text { tion \& RDF incineration } \\
\text { plant) }\end{array}$ & $\begin{array}{l}\text { value of land \& landfill } \\
\text { voidspace, material } \\
\text { sales (metal) }\end{array}$ \\
\hline
\end{tabular}

